Not all government policymakers share that view.

DOI: http://dx.doi/org/Io.6oI7/ihe.20I7.90.979I

\section{Uganda: Higher Education Modernization Needed}

\author{
Mukwanason A. Hyuha
}

Mukwanason A. Hyuha is emeritus professor of economics and consultant at Budembe Enterprises. E-mail: hyuhama@gmail.com.

Tn terms of quality, Uganda's education sector, modelled 1 on the basis of the British system, was one of the best in Africa until the early I990s. Thereafter, both the academic and physical infrastructures experienced serious declines in quality. Like in many other African countries, the higher education subsector in Uganda is currently facing various challenges-including, inter alia, underfunding across the board, inadequate academic staff at all levels, an acute shortage of senior staff, low remuneration packages for academic staff, inadequate facilities for graduate training, serious governance problems, low research output, scarcity of student scholarships, and suboptimal supervision of the sector by the mandated authorities. The main challenge is, however, underfunding.

Institutions of higher learning comprise 36 universities, four other degree-awarding institutions, and various certificate- and diploma-awarding institutions. The student population in these higher education institutions is just over 200,000 , of which 45 percent are women. These students represent about 2 percent of the entire population of learners in primary, secondary, and tertiary institutions in the country. In general, access to higher education by the poor is very problematic. Most of the students in these institutions come from well-to-do backgrounds. This is in contrast to access to primary and secondary education, which is broad and attainable by both rich and poor in general, in view of the ongoing universal primary and secondary education (UPE and USE) programs, implemented following the UN Declaration of September 2000. Further, many citizens of Kenya, Rwanda, Somalia, South Sudan, Tanzania, and other neighboring countries study in these institutions.

\section{Demand for Higher Education}

Since the mid-I980s, Uganda's higher education subsector has continued to register considerable growth in terms of institutions, primarily due to its high demand. Colleges of commerce and business studies dominate the subsector $(33$ percent), followed by universities (I 6 percent) and technical colleges (4 percent). Although Makerere University was the only degree-awarding institution in Uganda until I988, there are now 4I degree-awarding institutions in the country, of which II are public universities.

Overall, there is ample demand for university education, at least in the Eastern African region. This demand is far in excess of that for middle-level and technical education. This is a result of popular demand, intense advertising by universities, and the job market, which prefers degree holders to certificate and diploma holders. In addition, students who study science and technology have a better chance of being employed earlier, and more employment options, than those studying other disciplines. Consequently, most students, parents, and policy makers prefer university education to middle-level and technical education. This bias has led to a noticeable lack of middle-level technicians and workers, whom Uganda has to import. Hence, by 2016 ,

\section{Thereafter, both the academic and phys- ical infrastructures experienced serious declines in quality. Like in many other African countries, the higher education subsector in Uganda is currently facing various challenges}

less than ro percent of the training programs in health sciences and engineering were for diplomas. Needless to say, Uganda needs an immediate policy shift on this issue if it is to have the skilled labor needed to attract investment and propel economic growth and development.

Further, since the early I990s, there have been improvements in women's access to higher education, computer access and use, as well as enrollments in science and technology. The upsurge in enrollments has, however, been in business and computer-related disciplines, rather than in basic, mathematical, or other technical sciences. Factors to explain this include poor teaching facilities at secondary schools and underfunding, in addition to better employment opportunities in the articulated preferred areas. Due partly to the closing of technical institutes in favor of universities in the recent past, the production of middle-level technicians from technical institutions has, unfortunately, continued to decline.

The closing of lower-level tertiary training institutions was a retrogressive step, since middle-level technicians and artisans are indispensable in all construction and mainte- 
nance. Most of the growth of higher education institutions is in the commerce and business studies areas, rather than in the science and technical college fields.

Overall, the private sector owns 72 percent and the public sector 28 percent of the tertiary institutions. The overwhelming majority of students at the public universities are sponsored by private sources, not by government. In fact, apart from providing the required funding and other resources to the private tertiary education institutions, the private sector also plays a big role as a source of funding for the public tertiary institutions. Thus, the private sector plays a vital, complementary role in the provision of tertiary education in Uganda.

\section{Quality Up to the 1990s}

As noted, Uganda's quality of education at all levels used to be the best in Eastern Africa. The sound quality of education was sustained by a highly qualified team of instructors, well-equipped and well-funded institutions, adequate supporting services and staff, and good governance at all institutions. Despite political turbulence following the Idi Amin coup d'état of I97I, the quality remained reasonably high for at least two decades. Unlike today, it should also be noted that, at that time, there was hardly any corruption in the country, and student and teacher discipline and morale were very high. Unfortunately, corruption is now widespread in the country.

As noted earlier, many foreign students flocked to Uganda's secondary schools in search of quality education. Following admission of nongovernment sponsored students in 1992-1993, accompanied by the establishment of private universities since I988, many non-Ugandans also flocked to the country to benefit from sound quality university education. The fact that tertiary education in Uganda is generally cheaper than in neighboring countries also helped increase the demand, and, therefore, the number of foreign student inflows into the country.

After that, the situation changed for the worse-mainly due to serious underfunding. Currently, most higher education institutions are known for, inter alia, insufficient funding, overcrowded lecture halls, insufficient (and sometimes inexperienced and underqualified) instructors, inadequate teaching and learning materials, suboptimal numbers of senior academics, meagre or non-existent research output, and shortcomings in administration and other aspects of governance. In fact, all the universities are currently "bottom-heavy," with a serious lack of senior staff, particularly at the professorial levels. As for research, basically, only Makerere University can boast of reasonable annual research output; the other universities are essentially teaching universities with minimal research output. The situation at most institutions in terms of physical and edu- cational infrastructure and academic standards leaves a lot to be desired, just as in primary and secondary schools.

\section{THE WAY FORWARD}

Uganda needs to immediately modernize higher education-including rehabilitation and growth in the face of changing needs and technologies. Ultimately, this involves reshaping higher education in order to give it new life and a new relevance, including transforming institutions to meet changing social needs. This revitalization should culminate in improvements in its quality and quantity, strengthening existing systems and structures, filling existing gaps, diagnosing and dealing with deficiencies, and, consequently, enhancing sustainable development.

The higher education sector definitely needs overhauling. Annual government budget allocation to the entire education sector needs to be raised from its current low level (less than io percent of the budget) to at least I5 percent. Hence, increased funding, close supervision, and serious attention to solving the other challenges are essential in overcoming the multifaceted problems afflicting the subsector. Policy should target these variables.

DOI: http://dx.doi/org/ıo.6oI7/ihe.20I7.90.9787

\section{The Challenges of Creating a Ranking: A Colombian Example}

\section{Felipe Montes, David Forero, Ricardo Salas, and ROBERTO ZARAMA}

Felipe Montes is a postdoctoral researcher at the Department of Industrial Engineering, Universidad de los Andes, Colombia. E-mail: felmont@uniandes.edu.co. David Forero is lecturer, Faculty of Economic Sciences, Universidad Nacional de Colombia. E-mail: davidfforerot@ gmail.com. Ricardo Salas is manager at the Quality Assurance for Higher Education Office, ministry of education of Colombia. E-mail: jssalas@gmail.com. Roberto Zarama is full professor at the Industrial Engineering Department, Universidad de los Andes, Colombia. E-mail: rzarama@uniandes.edu.co.

$\mathrm{C}$ olombia is a country with a population of 48 million and 2.3 million students enrolled in higher education (49 percent access rate). For almost two decades, the Colombian government used a voluntary accreditation system to provide information to the population on the quality of higher education institutions. Even if accreditation has 